\title{
Penggunaan WebSite Sebagai Sarana Evaluasi Kegiatan Akademik Siswa Di SMA Negeri 1 Punggur Lampung Tengah
}

\author{
IkaArthalia $^{(1)}$ Rendi Prasetyo $^{(2)}$ \\ Jurusan Ilmu Komputer, Fakultas Ilmu Komputer,Universitas Muhammadiyah Metro \\ Jl.Gatot Subroto No.100 Yosodadi Kota Metro, Telpon :(0725)42445-Fax(0725)42454 \\ E-mail :ikaarthalia@gmail.com
}

\begin{abstract}
Abstrak
Penelitian ini merupakan hasil dari analisis dan observasi yang penulis lakukan terhadap sistem informasi yang sedang berjalan dan hasil perancangan yang baru dari website sebagai sarana evaluasi kegiatan akademik siswa di sma negeri 1 punggur lampung tengah. Peneliti menggunakan metode studi lapangan yaitu: pengamatan, wawancara, dan dokumentasi. Studi pustaka dengan mencari dan mempelajari sistem kerja yang berkaitan dengan penelitian. Pada saat ini pengolahan data akademik siswa pada SMA Negeri 1 Punggur masih manual, dan masih di temui beberapa permasalahan yaitu: a) waktu yang kurang efektif dalam pembuatan laporan dikarnakan kerumitan pemilihan data yang akan direkap, b) pencarian data yang kurang efektif karena harus membuka lembaran-lembaran buku.

Sedangkan bahasa pemrograman yang di gunakan untuk membuat aplikasi adalah Java dan database MySQL (XAMPP). Dengan menggunakan website sebagai sarana evaluasi kegiatan akademik siswa yang penulis buat, diharapkan SMA Negeri 1 Punggur lampung tengah dapat mengurangi permasalahan dalam mengolah data akademik siswa, mempercepat pencarian data dan perekapan laporan.
\end{abstract}

Kata Kunci: Website, Kegiatan Akademik Siswa, SMA 


\section{PENDAHULUAN}

Perkembangan teknologi informasi saat ini telah menjadi faktor yang mempengaruhi kehidupan di masyarakat, Seperti halnya internet, penggunaan internet dewasa ini sudah menjadi kebutuhan bagi masyarakat untuk mendapatkan informasi yang lebih cepat dan up to date. Sehingga dapat mempermudah masyarakat dalam mendapatkan suatu informasi.

Pendidikan di kalangan masyarakat sekarang ini berkembang dengan pesat. Setara dengan berkembangnya teknologi informasi sekarang ini, membuat para peserta didik ataupun staff pengajar lebih peka terhadap informasi - informasi pendidikan yang berbasis teknologi. Internet merupakan cabang perkembangan teknologi yang sudah biasa digunakan di kalangan masyarakat. Melalui internet ini pula, pendidikan di daerah - daerah terpencil juga bisa mendapatkan informasi yang baik dari pendidikan pusat dan mampu bersaing di dunia pendidikan. Perkembangan dari segala aspek ini, membuat para orang tua bisa lebih mudah dalam pengawasan perkembangan anak mereka melalui evaluasi berbasis online (web) sehingga hal ini lebih efektif bagi orang tua yang tidak sempat memantau perkembangan anak mereka melalui buku penghubung siswa. Kesibukan orang tua biasanya menjadi faktor utama dalam perkembangan anak di sekolah, maka terdapat beberapa siswa yang merasa kurangnya perhatian para orang tua terhadap perkembangan proses belajar - mengajar dan informasi akademik siswa di sekolah. Acuan tersebut merupakan alasan pembuatan sistem evaluasi akademik yang meliputi absensi, point pelanggaran, dan nilai siswa berbasis web. Karena diharapkan dengan adanya sistem tersebut para orang tua yang sibuk dapat mengontrol dan melihat perkembangan anak mereka dimana saja dan kapanpun.

SMA Negeri 1 Punggur yang beralamatkan di jalan raya Nunggalrejo Lampung Tengah dan mulai menerima siswa baru berdasarkan keputusan Kepala Dinas Pendidikan Pariwisata Seni dan Budaya Kabupaten Lampung Tengah Nomor : 420/003/05/D.8/2003 tanggal 17 Maret 2003, dengan demikian Kegiatan Belajar dan Mengajar SMA Negeri 1 Punggur dimulai pada Tahun Pelajaran 2003/2004 dan memiliki jumlah siswa sebanyak 919 siswa, yang masing-masing kelasnya kurang lebih memiliki 34 siswa untuk tahun pelajaran 2017/2018. SMA Negeri 1 Punggur memiliki 9 kelas untuk kelas X, 9 kelas untuk kelas XI, dan 9 kelas untuk kelas 
XII. SMA Negeri 1 Punggur memiliki 2 jurusan yaitu jurusan IPA dan IPS. SMA Negeri 1 Punggur sering memberikan informasi terbaru tentang perkembangan proses belajar siswa sekolah meliputi informasi absensi, point pelanggaran dan informasi nilai akademik di sekolah. Hal ini dilakukan dikarenakan pentingnya informasi tersebut bagi siswa dan juga kepada orang tua siswa dalam mengetahui perkembangan proses belajar siswa tersebut secara cepat, tepat, dan akurat. Namun dalam prosesnya informasi yang di berikan ini tidak dapat berjalan dengan baik, efektif, dan efisien. Informasi yang diterima oleh siswa dan orang tua siswa masih dilakukan secara manual yaitu dengan surat pamggilan yang diberikan setiap semester atau pun pertemuan dengan wali kelas dan guru bimbingan konseling. Beberapa kendala penggunaan surat panggilan yang sering dihadapi, guru, siswa, atau pun orang tua diantaranya adalah hilangnya surat, surat tidak tersampaikan, dan kesibukan orang tua yang tidak dapat memperhatikan proses belajar anaknya disekolah. Keluhan-keluhan ketika ingin mengakses informasi, seperti: kesulitan untuk bertemu dengan wali kelas, tidak sempat ke sekolah, dan lain lain. Dengan adanya beberapa kendala tersebut maka perlu dirancang suatu sistem untuk
93

mengakses informasi absensi, point pelanggaran siswa, dan informasi nilai akademik di sekolah berbasis WEB dengan menggunakan media internet. Pembuatan website ini digunakan untuk dapat mempermudah dan mempercepat serta menghemat biaya dalam mengakses informasi perkembangan proses belajar yang dibutuhkan oleh siswa dan orang tua siswa. Mengingat permasalahan yang dihadapi, SMA Negeri 1 Punggur sudah saatnya menerapkan sistem informasi tentang evaluasi kegiatan akademik siswa berbasis web.

\section{KAJIAN PUSTAKA DAN LANDASAN TEORI}

\subsection{Definisi Perancangan}

Perancangan merupakan suatu strategi untuk memecahkan masalah dan mengembangkan solusi terbaik permasalahan itu. Perancangan juga dapat di artikan sebagai tahap peroses pengembangan spesifikasi sistem yang memiliki tujuan untuk mendesain sistem baru berdasarkan rekomendasi analisasi sistem. Menurut kusrini dkk(2007:79) dalam bukunya "Tuntutan Praktis Membangun Sistem Informasi Akuntansi dengan Visual Basic dan Microfoft SQL Server" Perancangan adalah "Proses pengembangan spesifikasi sistem baru berdasarkan hasil 
rekomendasi

analisis

sistem".

Menurut Al-Bahra Bin Ladjamudin (2005:39) dalam bukunya yang berjudul "Analisis dan Desain Sistem Informasi". Adalah sebagai berikut "Tahapan Pempograman (design) memiliki tujuan untuk mendesain sistem baru yang dapat menyelesaikan masalah-masalah yang di hadapi perusahaan yang di peroleh dari pemilihan alternatif sistem yang terbaik". Dari beberapa definisi di atas dapat disimpulkan perancangan membutuhkan pengetahuan mengenai berbagai teknik maupun model perancangan yang dapat digunakan. Selain itu sebuah perancangan membutuhkan hasil ananlisis yang telah mampu mendeskripsikan kebutuhan dari sistem yang akan dibuat.

\subsection{Definisi WEBSITE}

Secara umum, website (web) dipahami sebagai sekumpulan halaman yang terdiri dari beberapa laman yang berisi informasi dalam bentuk digital baik itu teks, gambar, animasi yang disediakan melalui jalur internet sehingga dapat diakses dari seluruh dunia yang memiliki koneksi internet. Website awalnya merupakan suatu layanan sajian informasi yang menggunakan konsep hyperlink, yang memudahkan surfer atau pengguna internet melakukan penelusuran informasi di internet. Informasi yang disajikan dengan web menggunakan konsep multimedia, informasi dapat disajikan dengan menggunakan banyak media, seperti teks, gambar, animasi, suara, atau film. Sejumlah definisi atau pengertian website menurut para ahli berikut ini : Menurut Gregorius (2000:30) Website adalah kumpulan halaman web yang saling terhubung dan file-filenya saling terkait. Web terdiri dari page atau halaman, dan kumpulan halaman yang dinamakan homepage. Homepage berada pada posisi teratas, dengan halaman-halaman terkait berada di bawahnya. Biasanya setiap halaman di bawah homepage disebut child page, yang berisi hyperlink ke halaman lain dalam web. Sedangkan menurut Hakim Lukmanul (2004).Website merupakan fasilitas internet yang menghubungkan dokumen dalam lingkup lokal maupun jarak jauh. Dokumen pada website disebut dengan web page dan link dalam website memungkinkan pengguna bisa berpindah dari satu page ke page lain (hyper text), baik diantara page yang disimpan dalam server yang sama maupun server diseluruh dunia. Pages diakses dan dibaca melalui browser seperti Netscape Navigator, Internet Explorer, Mozila Firefox, Google Chrome dan aplikasi browser lainnya. 


\subsection{World Wide Web (WWW)}

WWW adalah kepanjangan dari World Wide

Web, dan Pengertian www adalah sebuah sistem yang digunakan untuk mengirimkan dan menyebarkan data ke jaringan internet berskala besar yang ada di seluruh penjuru dunia. www sering dianggap sama dengan internet secara keseluruhan, walaupun sebenarnya hanya istilah bagian dari internet. Sejarah www yaitu pertama kali dikembangkan di Pusat Penelitian Fisika Partikel Eropa, Jenewa Swiss sekitar tahun 1989 Berners-lee membuat proposal untuk proyek pembuatan hypertext secara global. Ketika pertama kali dikenalkan ke publik pada tahun 1995. www benar-benar menjadi perhatian masyarakat dunia internet. Www adalah informasi yang dapat diakses melalui internet di mana dokumen dokumen hypermedia (file - file komputer) disimpan dan kemudian diambil dengan cara - cara yang menggunakan metode penentuan alamat yang unik.

\subsection{HTTP}

HTTP (Hypertext Transfer Protocol) merupakan istilah yang diberikan pada sebuah protokol dan dipergunakan untuk mengirimkan dokumen dari WWW (World Wide Web). HTTP dapat pula diartikan sebagai protokol jaringan untuk pendistribusian sistem informasi hypermedia secara kolaboratif. Protokol HTTP sendiri pertama kali digunakan pada sekitaran tahun 1990. Saat itu, yang dipakai adalah HTTP versi 0,9 yang masih berupa mentahan protokol transfer data. Artinya, data dikirimkan tanpa melihat tipe dokumen yang dikirimkan. Lalu sekitar 6 tahun kemudian pada 1996, terdapat perkembangan dari protokol HTTP sehingga berubah menjadi HTTP versi 1.0. Versi ini masih terus dikembangkan hingga pada 1999 diluncurkan versi 1.1 yang sudah berhasil mengakomodasi proxy, cache,serta koneksi yang persisten.

\subsection{HTML}

\section{Hypertext Markup Language (HTML)} adalah sebuah bahasa markah yang digunakan untuk membuat sebuah halaman web, menampilkan berbagai informasi di dalam sebuah penjelajah web Internet dan pemformatan hiperteks sederhana yang ditulis dalam berkas format ASCII agar dapat menghasilkan tampilan wujud yang terintegerasi. Dengan kata lain, berkas yang dibuat dalam perangkat lunak pengolah kata dan disimpan dalam format $\underline{\mathrm{ASCII}}$ normal sehingga menjadi halaman web dengan perintah-perintah HTML. Bermula dari sebuah bahasa yang sebelumnya banyak digunakan di dunia penerbitan dan 
percetakan yang disebut dengan SGML (Standard Generalized Markup Language), HTML adalah sebuah standar yang digunakan secara luas untuk menampilkan halaman web. HTML saat ini merupakan standar Internet yang didefinisikan dan dikendalikan penggunaannya oleh World Wide Web Consortium (W3C). HTML dibuat oleh kolaborasi Caillau TIM dengan Berners-lee Robert ketika mereka bekerja di CERN pada tahun 1989 (CERN adalah lembaga penelitian fisika energi tinggi di Jenewa).

\subsection{Database}

Basis data (database) adalah kumpulan data yang disimpan secara sistematis di dalam komputer yang dapat diolah atau dimanipulasi menggunakan perangkat lunak (program aplikasi) untuk menghasilkan informasi. Pendefinisian basis data meliputi spesifikasi berupa tipe data, struktur data dan juga batasan-batasan pada data yang akan disimpan. Adapun pengertian Database menurut para ahli adalah sebagai berikut : Edhy Sutanta (2005:18) yang mengutip dari James Martin mendefinisikan "basisdata adalah suatu kumpulan data terhubung (interrelated data) yang di simpan secara bersama-sama pada suatu media, tanpa mengatap satu sama lain atau tidak perlu suatu kerangkapan data”. Menurut Hartono
(2005:13) mendefinisikan "Basis data (database) adalah kumpulan dari data yang saling berhubungan satu dengan yang lainnya, tersimpan diperangkant keras komputer dan digunakan di perangkant lunak untuk memanipulasinya."

\subsection{Internet}

Interconncted Network atau yang lebih popular dengan sebutan internet adalah sebuah sistem komunikasi global yang menghubungkan computer - computer dan jaringan - jaringan computer di seluruh dunia. Yeni Kustiyahningsih dan Devie Rosa Anamasia "Internet adalah sebuah jaringan komputer”. Berdasarkan pengertian internet diatas dapat disimpulkan internet merukan seluruh jaringan yang saling terhubung secara fisik dan memiliki kemampuan untuk membaca dan menguraikan protocol komunikasi dengan jumlah pengguna lebih dari 200 negara.

\subsection{Definisi Data}

Data berasal dari bahasa latin, datum(tunggal), pemberian, karunia, sajian; data (jamak), hadiah-hadiah, sajiansajian.Untuk lebih memahami definisi tentang data berikut beberapa pendapat yang dikemukakan oleh para ahli antara lain: Menurut EDI SUTANTA (2005:4) “data 
dapat di definisikan sebagai bahan ketengan kejadian-kejadian Nyata atau fakta-fakta yang dirumuskan dalam sekelompok lambang tertentu yang tidak acak dan menunjukan jumlah tindakan atau suatu hal'.Sedangkan menurut Wilkinson yang dikutip oleh Abdul Kadir (2009:3) mengatakan bahwa: "Data adalah fakta, angka, bahkan simbol mentah. Secara bersama-sama merupakan masukan bagi suatu sistem informasi”. Dari beberapa definisi diatas dapat disimpulkan bahwa data adalah suatu kejadian yang diangkat dari suatu kenyataan (fakta) dapat berupa angkaangka, huruf, simbol-simbol tertentu, atau gabungan dari ketiganya. Data belum dapat ditafsirkan sehingga perlu diolah agar menghasilkan informasi untuk pengambilan suatu keputusan.

\subsection{Definisi Pengolahan Data}

Pengolahan data berasal dari gabungan kata yaitu "pengolahan" dan "data" yang masingmasing memiliki definisi. Berikut definisi pengolahan data : "Pengolahan data adalah suatu proses yang menerima data sebagai masukan (input), memprosesing (proccesing) menggunakan program tertentu dan mengeluarkan hasil proses data tersebut dalam bentuk informasi (output)". Dari definisi diatas dapat disimpulkan bahwa pengolahan data adalah suatu cara agar data dapat diolah menjadi sesuatu yang lebih berguna dan dapat ditafsirkan sehingga bisa dimengerti oleh orang lain dalam bentuk informasi yang nantinya dapat diambil sebuah keputusan.

\subsection{Pengertian Evaluasi}

Evaluasi adalah Suatu usaha untuk memperoleh berbagai informasi secara berkala, berkeseimbangan dan menyeluruh terhadap semua aspek perkembangan. Evaluasi merupakan saduran dari bahasa Inggris "evaluation" yang diartikan sebagai penaksiran atau penilaian. . Berdasaran buku Evaluasi Program dan Instrumen Evaluasi Raplh Tyler (2008:3) "menyatakan bahwa evaluasi adalah proses yang menentukan sampai sejauh mana tujuan pendidikan dapat di capai”. Stufflebeam (1971) menjelaskan bahwa "Evaluasi adalah menyediakan informasi untuk membuat suatu keputusan". Maka dari pengertian diatas, dapat disimpulkan bahwa evaluasi adalah proses menetukan nilai untuk suatu hal atau objek yang berdasarakan pada acuan-acuan tertentu untuk menentukan tujuan tertentu. Dalam perusahaan, evaluasi dapat diartikan sebagai proses pengukuran akan evektivitas strategi yang digunakan dalam upaya 
mencapai tujuan perusahaan. Data yang diperoleh dari hasil pengukuran tersebut akan digunakan sebagai analisis situasi program berikutnya.

\subsection{Prestasi Akademik}

Prestasi akademik adalah hasil belajar yang dicapai oleh seorang siswa pada periode tertentu.

Jadi yang dimaksud dengan Evaluasi Prestasi Akademik adalah upaya yang dilakukan untukmemperoleh informasi penyebab keberhasilan dan kegagalan berkaitan dengan hasil belajar yang dicapai seorang siswa dalam periode waktu tertentu.

\subsection{Manfaat Evaluasi}

Modal dasar untuk memperbaiki kesalahan/ketidak sempurnaan adalah dengan mengetahuiletak kesalahan itu sendiri. Sebagai ilustrasi : rumah yang gentengnya bocor, insinyur sehebatapapun tidak akan mampu memperbaiki dengan sempurna jika tidak mengetahui letak kebocorandan penyebabnya. Demikian juga dengan pretasi akademis, bagaimana siswa akan memperbaikinilainya jika tidak mengetahui letak kesalahan dan penyebabnya. Untuk itulah pentingnyadilakukan langkah evaluasi, dan evaluasi merupakan suatu tahapan yang sangat penting dalamsetiap akhir suatu kegiatan.
98

3.3 Devinisil dreamweaver cs6 Macromedia dreamweaver CS6 merupakan perangkat lunak atau software yang berfungsi sebagai editor untuk membangun dan mendesain suat website seperti halnya Artisteer. Selain itu Dreamweaver juga berintengerasi dengan beberapa perangkat lunak lainnya. Dreamweaver CS6 mempunyai kelebihan dari tipe sebelumnya, antara lain penggunaan fitur canggih Ajax, JQuery yang menggunakan Browser Widged serta pengujian tampilan web menggunakan Web Adobe Browser Lab.

\section{METODE}

Metode adalah kesatuan metode-metode yang digunakan oleh suatu ilmu pengetahuan dalam memperoleh data.

1. Studi Lapangan

Studi Lapangan adalah pengumpulan data yang secara langsung mempelajari yang berkaitan dengan masalah yang sedang dihadapi. Adapun studi lapangan yang penulis lakukan adalah dengan teknik:

a. Pengamatan (observation)

Dengan cara melakukan penelitian secara langsung pada SMA Negeri 1 Punggur sehingga penulis dapat mengetahui secara langsung tentang alur sistem data pelanggaran yang berjalan pada saat ini. Terlampir foto-foto penelitian.

b. Metode wawancara (interview) 
Digunakan untuk mendapatkan data dengan melakukan tanya jawab secara langsung dengan pihak yang berkaitan dan berkompeten yaitu guru Bimbingan Konseling (BK), siswa dan orangtua siswa, Terlampir pada tabel wawancara.

c. Dokumentasi (documentation)

Dokumentasi yaitu penelitian yang penulis lakukan dengan cara mengumpulkan dokumen yang dibutuhkan untuk merancang sebuah website evaluasi nilai akademik siswa. Adapun dokumen yang di dapat sebagai berikut: data absensi, point pelanggaran dan nilai akademik siswa. Terlampir data atau dokumen penelitian

\section{Studi Pustaka}

Studi pustaka yang penulis lakukan untuk menambahkan beberapa hal yang tidak penulis dapatkan dalam studi lapangan. Dengan cara mengumpulkan data dengan membaca buku-buku dan mempelajari literatur yang berkaitan dengan masalah yang dihadapi.

\section{HASIL DAN PEMBAHASAN}

Dari hasil penelitian pada bagian Bimbingan dan Konseling khususnya pelanggaran siswa yang dilaksanakan di SMA NEGERI 1 PUNGGUR telah ditemukan permasalahan yaitu belum adanya sistem komputerisasi untuk mengolah data pelanggaran siswa yang masih menggunakan buku besar sebagai media penyimpanan data. Pencarian data pelanggaran per siswa dan pembuatan laporan pelanggaran siswa pun membutuhkan waktu yang cukup lama karena belum adanya database sebagai media penyimpanan. Oleh karena itu dibuatlah PERANCANGAN WEBSITE SEBAGAI SARANA EVALUASI KEGIATAN AKADEMIK SISWA DI SMA NEGERI 1 PUNGGUR LAMPUNG TENGAH yang akan memudahkan Orangtua dalam memantau atau mengawasi anaknya disekolah dan akan lebih cepat dan akurat.

\subsection{Rancangan Diagram Konteks}

Pada Gambar 4.1 menggambarkan rancangan website evaluasi akemik siswa pada SMA Negeri 1 PUNGGUR Lampung Tengah. Staff tatausaha mengolah data absen,nilai, dan pelanggaran lalu input data kedalam sistem informasi agar walimurid dapat melihatnya.

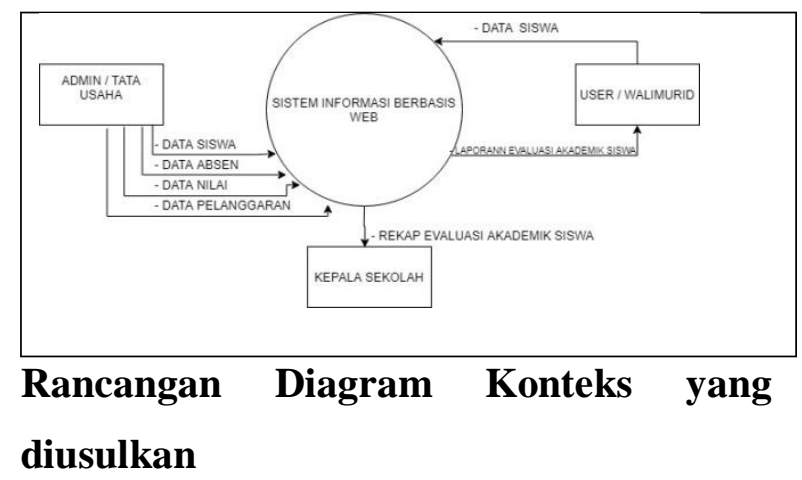




\section{JIKI}

\subsection{Rancangan Data Flow Diagram (DFD)}

\section{Level 1}

Rancangan Data Flow Diagram level nol penjelasan lebih rinci dari Diagram konteks sebelumnya.

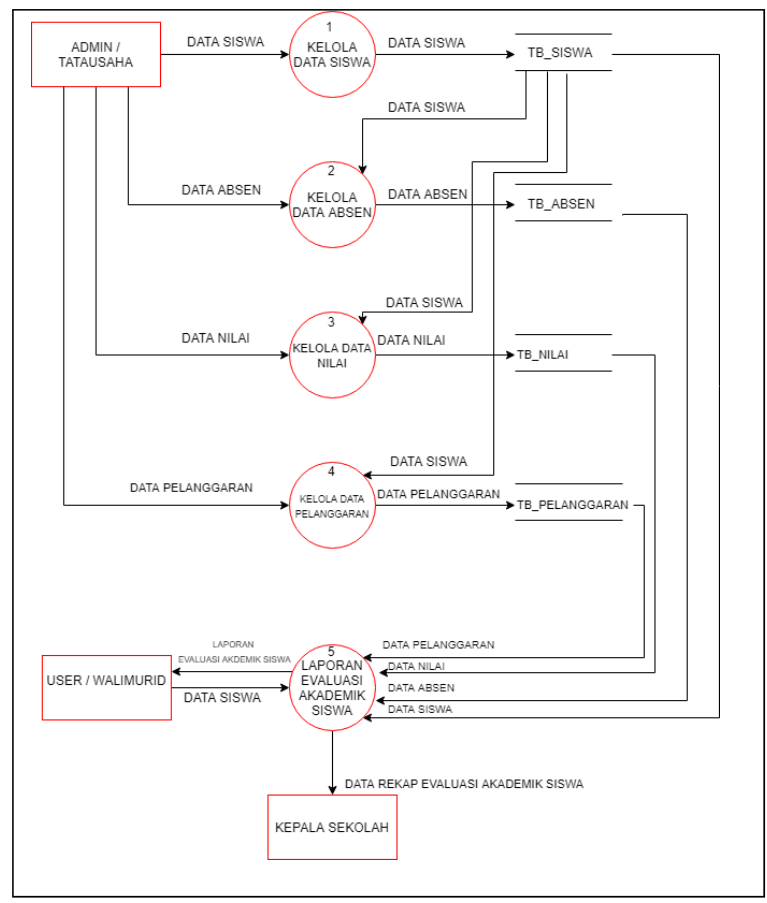

Data Flow Diagram (DFD) level satu yang diusulkan

\subsection{Rancangan Bagan Alir Dokumen (Flowchart)}

Rancangan bagan alir dokumen-dokumen, proses-proses serta pihak-pihak yang terlibat di dalamnya :

\begin{tabular}{|l|l|}
\hline $\begin{array}{l}\text { Admin / Tata } \\
\text { usaha }\end{array}$ & $\begin{array}{l}\text { User } \\
\text { Walimurid }\end{array}$ \\
\hline
\end{tabular}

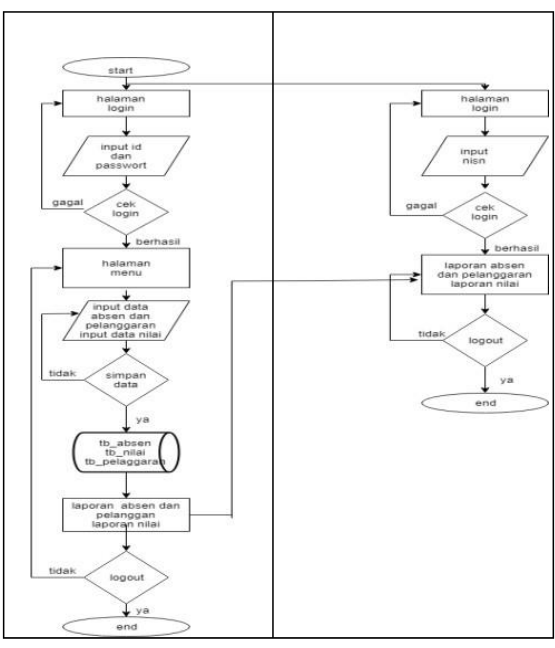

Bagan Alir Dokumen (Flowchart) yang diusulkan

\subsection{Rancangan Entity Relationship} diagram (ERD)

ERD dibuat untuk menggambarkan atau membuat model suatu database dengan diagram yang sederhana sehingga memudahkan dalam membuat sebuah database yang kompleks maupun yang sederhana.

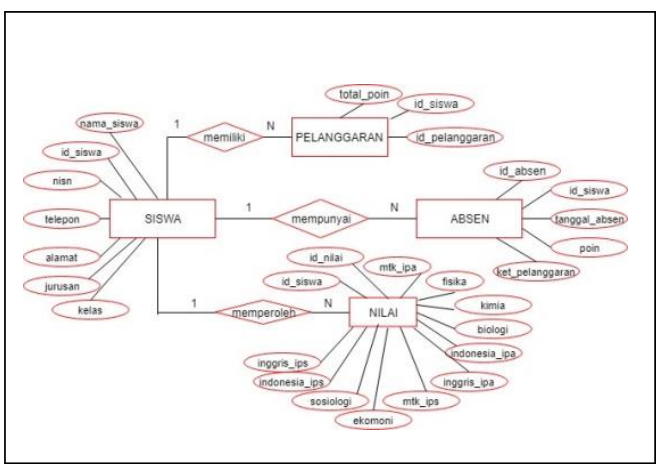

Entity Relationship Diagram (ERD) yang

Diusulkan 


\subsection{Hasil Perancangan Website}

Halaman admin digunakan untuk proses menajemen data (input, edit, dan delete data) yang akan ditampilkan pada website. Admin harus login dengan username dan passwort untuk masuk kehalaman admin, dan bila ingin keluar harus mengeklik tombol logout. Hasil perancangan halalaman admin sebagai berikut;

1. Tampilan Halaman Login admin

Halaman login digunakan oleh admin untuk login.

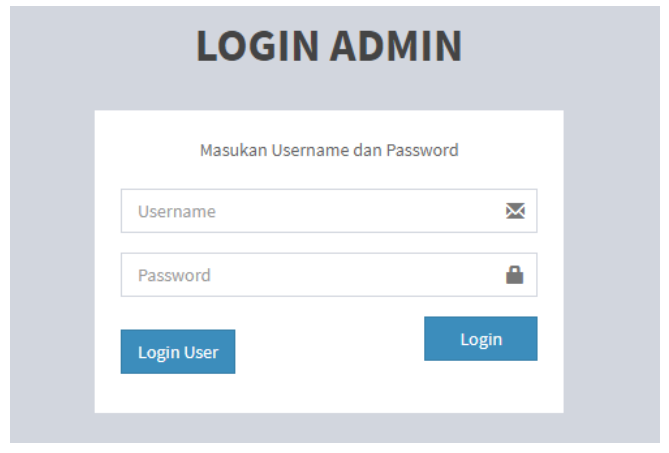

Tampilan halaman login admin

Fungsi-fungsi tombol:

Log In : untuk masuk ke menu utama admin.

Login user : untuk login ke halaman user.

2. Tampilan hasil perancangan halaman utama admin
Halaman utama admin adalah halaman utama untuk mengelola website ini seperti; input data,edit data, dan delete data yang akan di tampilkan pada halaman user.

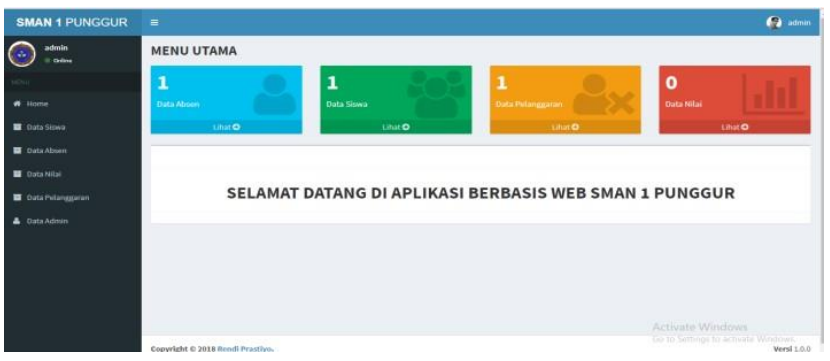

Tampilan halaman utama admin

Fungsi toolbar :

Home : untuk kembali

kehalaman awal menu utama admin.

Data siswa : untuk input data siswa.

Data absen : untuk input data absen.

Data nilai : untuk input data nilai.

Data pelaggaran : untuk input pelangan siswa.

3. Tampilan halaman login user

Halaman login user digunakan oleh pengguna untuk masuk ke halaman utama 
user.

\section{LOGIN USER / WALI} MURID

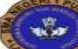
F,

NISN

Masukan NISN Dengan Benar

Login Admin

Copyright $@ 2018$ Rendi

Tampilan login user

Login user dapat dilakukan dengan memasukan NISN siswa lalu klik tanda panah.

4. Tampilan halaman user

Halaman user merupakan halaman utama pada web dimana pengunjung dapat mengetahui.

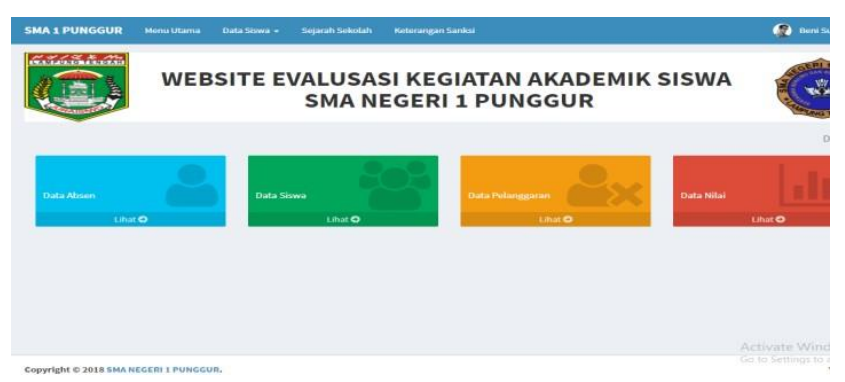

Tampilan halaman user

Fungsi toolbar :

Home : untuk kembali

kehalaman awal menu utama user.

Data siswa : : untuk melihat data

siswa.

Data absen : untuk melihat data absen.
Data nilai : untuk melihat data

nilai.

Data pelaggaran : untuk melihat data pelangan siswa.

\section{Tampilan cetak laporan}

Cetak laporan merupakan hasil cetak dokumen dari informasi yang ditampilkan pada website ini. Adapun tampilan cetak laporan yaitu sebagai berikut;

a. Tampilan cetak laporan absen

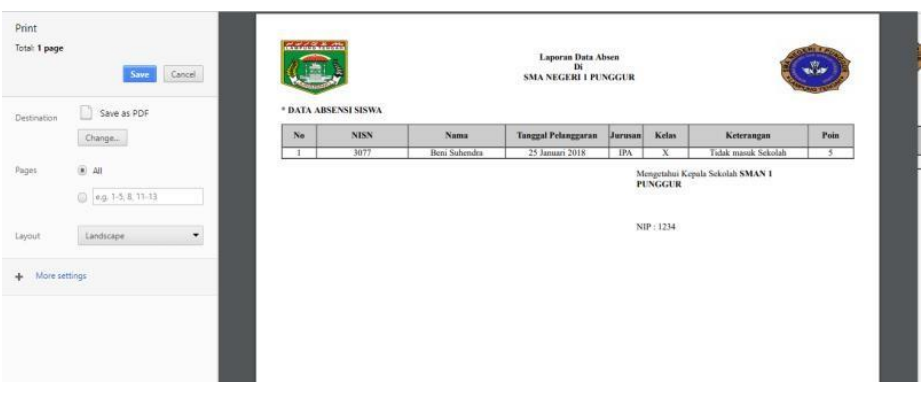

Gambar 4.23 cetak laporan absen

b. Tampilan cetak laporan nilai

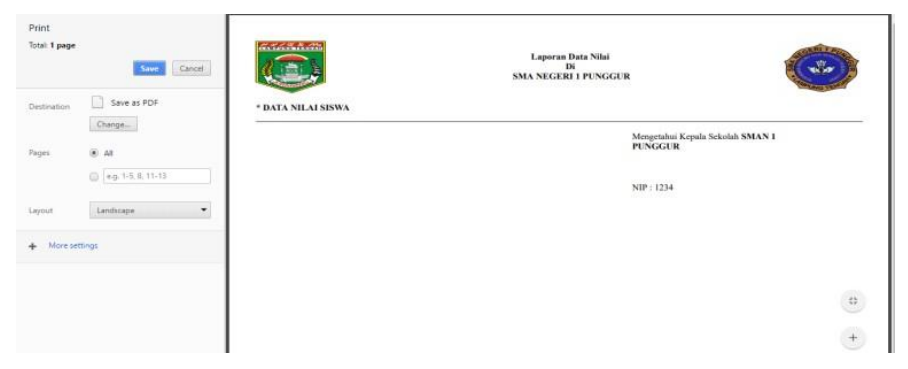

Cetak laporan nilai

Keteranngan : Nilai hanya di update tiap akhir semester.

c. Tampilan cetak laporan pelanggaran 


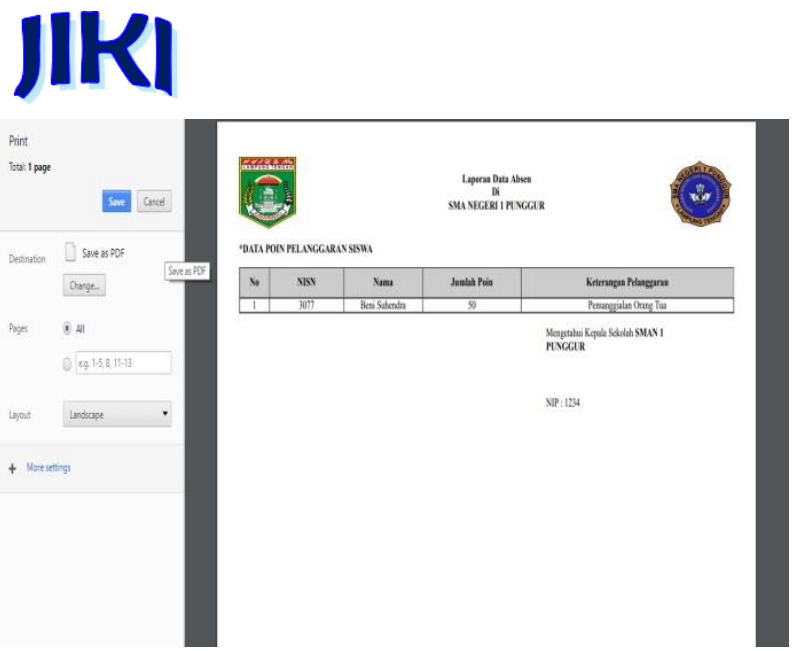

Cetak laporan pelanggaran

\section{A. Tahap Unggah Web Di Hosting}

Cara unggah web ke hosting :

1. Sebelum upload web ke hosting backup file website localhost lalu block all file dan folder di dalamnya untuk di extrak file.zip dan backup SQL Localhost pilih semua lalu di export. Simpan pada folder baru yang mudah untuk ditemukan.

2. Membuat database

Setelah anda mempersiapkan atau memiliki sebuah hosting dan memenuhi kebutuhan system, langkah selanjutnya adalah membuat sebuah database.

Silahkan login pada hosting anda, user ID untuk login hosting anda dikirimkan melalui akun email yang anda daftarkan pada saat pembelian hosting tersebut.

a. Setelah login, pada panel DATABASES silahkan klik MySQL Databases.
103

b. Pada halaman MySQL Databases buatlah sebuah database dan copy nama database yang anda buat pada notepad.

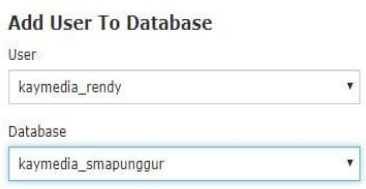

Add

Current Users

Users

Actions

Membuat database

3. Membuat user database

a Setelah pembuatan databases selesai, buat juga sebuah user database dengan passwordnya. Silahkan copy pada notepad user database dan password yang anda buat.

b. Setelah membuat Database_Name dan User_Database, Add Previlage User to Database.

4. Upload Backup localhost ke hosting Kembali ke beranda anda, pada panel FILES silahkan klik File

Manager. Root_directory anda

adalah public_html, jadi silahkan klik public_html pada daftar table sisi sebelah kiri. Klik Upload pada menu bar atas, pada halaman selanjutnya klik SELECT FILE. Pada jendela explorer yang terbuka silahkan cari folder website anda, dimana 
anda telah membuat backup berupa file zip. Klik atau pilih file zip yang merupakan backup file website localhost anda, klik OPEN. Silahkan tunggu proses upload sampai selesai, setelah selesai klik Go Back to "/home/prefixanda/nama-domain-anda.com".

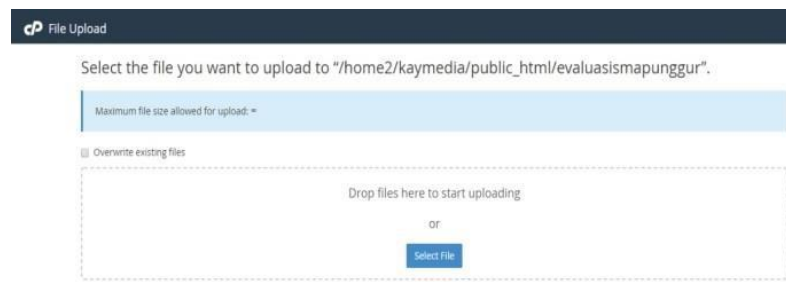

Upload Backup localhost ke hosting

\section{Extrac File Hasil Upload}

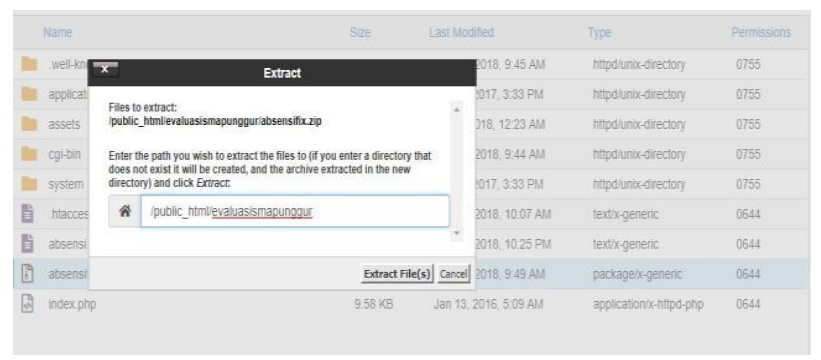

Extrac File Hasil Upload

6. Setelah anda klik Go Back to “/home/prefix-anda/nama-domainanda.com", pada antar muka File Manager anda akan melihat file zip yang telah anda upload sebelumnya. Klik file tersebut, lalu klik EXTRACT, tunggu sampai proses extract selesai.
104

Setelah proses extract selesai, buka poincludes/core/config.php dan sesuaikan:

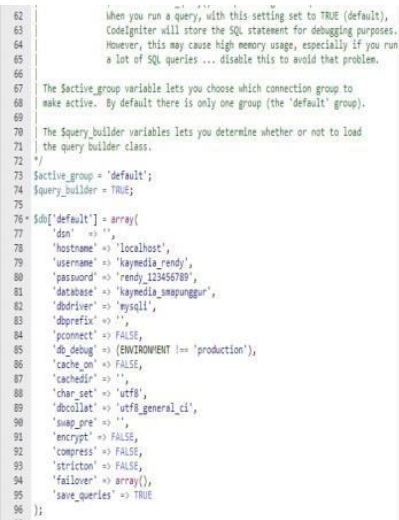

Setting koneksi

\section{Import File SLQ}

Silahkan cari dahulu dimana anda menyimpan file SQL hasil backup localhost phpmyadmin. Jika anda sudah mengingatnya, sekarang kita lanjutkan. Pada antar muka hosting anda, pada panel DATABASES, silahkan klik Phpmyadmin. Pada halaman Phpmyadmin, anda akan melihat nama database yang anda buat sebelumnya diawali dengan prefix. Silahkan klik nama database anda, lalu klik import pada menu bar atas, klik Browse..., cari dimana file SQL hasil backup localhost yang anda buat. Jika sudah anda temukan silahkan klik, lalu klik open, klik Go. 


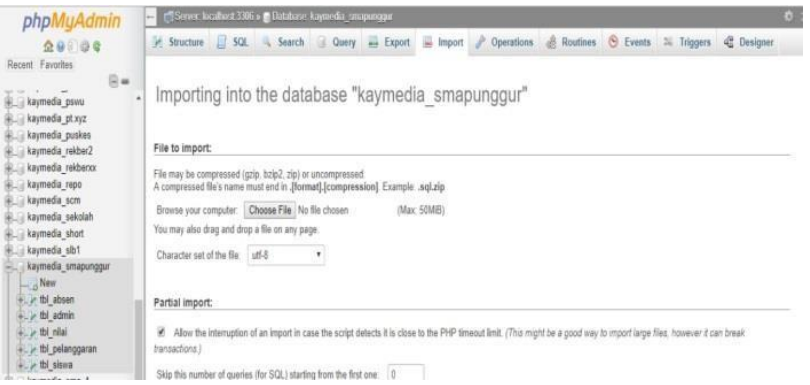

File import SQL

\section{Setting URL}

Jika import file SQL selesai, silahkan reload halaman Phpmyadmin, klik pada table setting. Pada kolom setting URL silahkan klik Edit, lalu sesuaikan URL website anda seperti berikut:

Web_Url

$=>$ "http://evaluasismapunggur.kaymedia.ne

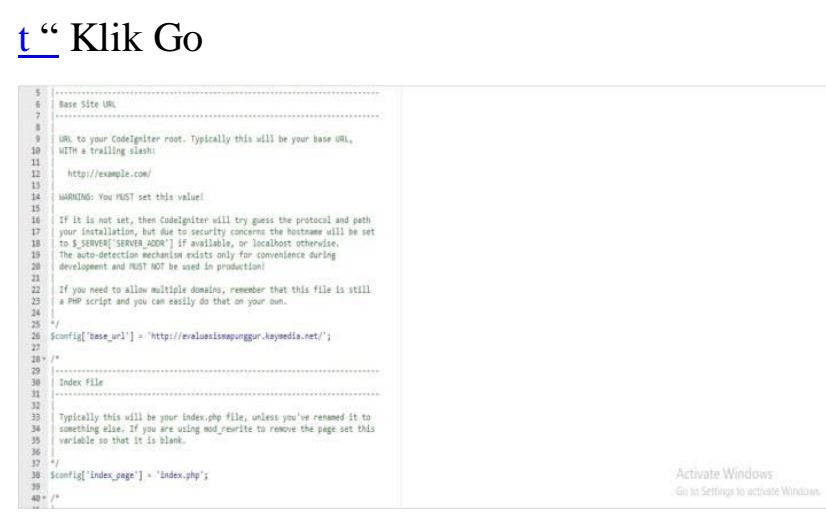

Setting URL

9. Akses melalui browser

Silahkan buka browser anda lalu akses URL Website.

10. Selesai.

\section{KESIMPULAN}

Berdasarkan analisis yang telah diuraikan pada bab sebelumnya,penulis menyimpulkan pembahasan yaitu,seperti:

1. Perancangan website evaluasi akademik siswa SMA Negeri 1 Punggur dibangun dengan menggunakan PHP,MySQL sebagai databasenya dengan program XAMPP. mempermudah orangtua dalam mendapatkan informasi tentang evaluasi akademik anaknya dan jauh lebih efektif digunakan untuk di bandingkan dengan sistem sebelumnya.

2. Dengan adanya Sistem informasi sebagai sarana evaluasi akademik siswa berbasis web pada SMA Negeri 1 Punggur lampung tengah, dapat memperbaiki sistem informasi yang sebelumnya masih dilakukan secara langsung (face to face).

3. Dapat mencetak laporan informasi dengan cepat dan akurat. 


\section{DAFTAR PUSTAKA}

[1] Gregorius.(2000:30) . "Pengertian Website" Hartono, Jogiyanto. 1995. Teori dan Aplikasi Program Komputer.Yogyakarta: ANDI.

[2] Hartanto, Jogianto. 2005. Analisis dan Desain Yogyakarta: ANDI.

[3] Kadir, Abdul. 2009. Desain Perancangan dan Implementasi Yogyakarta: ANDI.

[4] Kadir, Abdul. 2003 Pengenalan Sistem Informasi. Yogyakarta: ANDI Yogyakarta.

[5] Kholid, Krisman Hudaya. 2015. Java Dekstop Dengan Metode Pro OOP Yokyakarta: ANDI.

[6] Kusrini,dkk.(2007:79) "Tuntunan Praktis Membangun Sistem Informasi Akuntasi" dengan Visual Basic dan Microsoft SQL Server",. (http://noficahyono.com/2015/07/per ancangan-sistem-informasi 13.html. Diakses Mei 2018)

[7] Ladjamudin, AL-Bahra bin. 2005 Analisis dan Desain Sistem Informasi.Yogyakarta: Graha lmu.

[8] Nugroho. Adi. 2011. Perancanga Dan Implementasi Sistem Basis Data. Andi Offset. Yogyakarta.

[9] Raharjo, Budi. 2016.Modul Pemrograman Web, Bandung: Modula.Offset, Andi (2012:282). "adobe dreamweaver CS6 dan PHP-MySQL untuk pemula"

[10] Sutanta, Edi. 2005. Sistem Basis Data. Yogyakarta: Graha Ilmu.

[11] Tayibnapis, Dr Farida. 2008. Evaluasi Program dan Intrumen Evaluasi. Jakarta: Rineka Cipta. 
